\title{
EFEITO DA POPULAÇÃO DE PLANTAS E DO ESPAÇAMENTO SOBRE A PRODUTIVIDADE DE MILHO
}

\author{
DURVAL DOURADO NETO ${ }^{1}$, MARCOS PALHARES ${ }^{2}$, PEDRO ABEL VIEIRA ${ }^{3}$, PAULO \\ AUGUSTO MANFRON ${ }^{4}$, SANDRO LUIS PETTER MEDEIROS ${ }^{5}$, MARCELO RIBEIRO ROMANO ${ }^{6}$ \\ ${ }^{1}$ Bolsista CNPq, .Dr., Professor Associado, Departamento de Produção Vegetal, ESALQ-USP. CEP. 13418-900 Piracicaba, \\ SP.E-mail: dourado@esalq.usp.br (autor para correspondência) \\ ${ }^{2}$ Eng. Agrônomo, MSc. Monsanto do Brasil. Rua João Vicentini 118, CEP. 18706-340 Avaré, SP. E-mail: \\ palhares@monsanto.com.br \\ ${ }^{3}$ Pesquisador, MSc., Embrapa Milho e Sorgo - SNT. Caixa Postal 151, CEP. 35900-470 Sete Lagos, MG. E-mail: \\ pavieira@cmpns.embrapa.br \\ ${ }^{4}$ Bolsista CNPp, Dr., Professor Titular, Departamento de Fitotecnia, CCR, UFSM. CEP. 97105-900 Santa Maria, RS. E- \\ mail:manfronp@ccr.ufsm.br \\ ${ }^{5}$ Dr., Professor Adjunto, Departamento de Fitotecnia, CCR, UFSM. CEP. 97105-900 Santa Maria, RS. E-mail: \\ sandro@ccr.ufsm.br \\ ${ }^{6}$ Eng. Agrônomo, MSc., Doutorando em Fitotecnia, ESALQ-USP. CEP. 13418-900 Piracicaba, SP. E-mail: \\ mrromano@esalq.usp.br.
}

Revista Brasileira de Milho e Sorgo, v.2, n.3, p.63-77, 2003

RESUMO - Para avaliar o efeito da população de plantas (30.000, 60.000 e 90.000 plantas $\left.\mathrm{ha}^{-1}\right)$, sob dois espaçamentos $(0,40$ e $0,80 \mathrm{~m})$, sobre o rendimento de grãos de três genótipos de milho com arquiteturas foliares aberta (AG 1051), semi-ereta (AG 7575) e ereta (DKB 911), foi conduzido um experimento em Piracicaba-SP, no período de 20 de novembro de 2000 a 10 de abril de 2001. Pôde-se concluir que: a) na maior população, a redução do espaçamento de $0,80 \mathrm{~m}$ para $0,40 \mathrm{~m}$ teve efeito positivo no rendimento de grãos no genótipo de arquitetura foliar aberta; b) até 60.000 plantas ha $^{-1}$, independentemente do genótipo, $\mathrm{o}$ rendimento de grãos é crescente com o aumento da população de plantas. Com o aumento da população de plantas de 60.000 para 90.000 plantas ha $^{-1}$, o rendimento de grãos: a) aumenta no genótipo de arquitetura foliar ereta; b) estabiliza-se, no genótipo de arquitetura semi-ereta; c) estabiliza-se, sob o menor espaçamento, ou diminui sob espaçamento de $0,80 \mathrm{~m}$, no genótipo de arquitetura aberta.

Palavras-chave: Zea mays, milho, rendimento de grãos, população de plantas.

\section{DISTRIBUITION AND POPULATION OF PLANTS AND MAIZE GRAIN YIELD}

\begin{abstract}
With the purpose of evaluating the effect of plant population $(30,000 ; 60,000$ and 90,000 plants ha $\left.^{-1}\right)$, under two width rows $(0.40$ and $0.80 \mathrm{~m})$, on the grain yield of three maize genotypes with open (AG 1051), semi-erect (AG 7575) and erect (DKB 911) leaf architecture, a field experiment was carried out in Piracicaba, São Paulo, Brazil between November $20^{\text {th }}, 2000$ and April $10^{\text {th }}, 2001$. According to the results: a) in high population $\left(90,000\right.$ plants ha $\left.^{-1}\right)$, the reduction of width row (from $0.80 \mathrm{~m}$ to $0.40 \mathrm{~m}$ ) increases grain yield on the open-leaf-architecture genotype, and b), until 60,000 plants ha ${ }^{-1}$, regardless of genotype, the grain yield is crescent with an increase in plant population. With the plant population increasing from 60,000 to 90,000 plants $^{-1} \mathrm{a}^{-1}$, the grain yield: a) increases in the erect-leaf-architecture
\end{abstract}


genotype, b) stabilizes on the semi-erect-leaf-architecture genotype, c) stabilizes under reduced spacing $(0.40 \mathrm{~m})$, and decreases under spacing of $0.80 \mathrm{~m}$ in the open-leaf-architecture genotype.

key words: Zea mays, corn, grain yield, plant population.

No Brasil, o milho é cultivado em aproximadamente 13 milhões de hectares, e a área de maior concentração da produção e adoção de tecnologia está localizada nos estados da região Sul do país, além de São Paulo, Minas Gerais e Goiás (Conab, 2002). Enquanto o rendimento médio nacional é de $3.341 \mathrm{~kg} \mathrm{ha}^{-1}$, a média mundial é de $6.500 \mathrm{~kg} \mathrm{ha}^{-1}$, sendo que diversos fatos apontam para a necessidade de intensificação de pesquisas e de adoção de tecnologia na cultura.

Tradicionalmente, o espaçamento entre linhas adotado pela maioria dos produtores brasileiros concentra-se entre 0,80 e $0,90 \mathrm{~m}$, devido, principalmente, à inadequação das colhedoras em sistemas que adotam espaçamentos inferiores a 0,80 $\mathrm{m}$. Entretanto, já há disponibilidade no mercado de semeadoras e colhedoras que permitem a adoção de espaçamentos entre linhas de até $0,45 \mathrm{~m}$. Isso viabilizou a utilização de até 72.000 plantas de milho por hectare, sob espaçamento entre linhas de $0,55 \mathrm{~m}$, com aumento de produtividade (Fancelli \& Dourado Neto, 2000).

Em razão do aumento na interceptação de luz e do melhor aproveitamento da água e nutrientes disponíveis, acréscimos na produtividade podem ser obtidos pelo aumento da densidade de semeadura, associado à redução do espaçamento entre linhas. A redução da competição inter e intraespecífica por esses fatores de produção, obtida pelo melhor arranjo espacial entre as plantas, dá-se pelo aumento da área foliar por unidade de área, a partir dos estádios fenológicos iniciais (Johnson et al.,1998; Molin, 2000). Citam-se, como exemplo, dados relativos a período superior a dez anos, em áreas de produção comercial no Estado de Ohio, EUA, em que o incremento médio de produtividade de milho alcançado pela redução do espaçamento de $0,76 \mathrm{~m}$ para $0,50 \mathrm{~m}$ foi de, aproximadamente, $340 \mathrm{~kg} \mathrm{ha}^{-1}$. Pesquisas realizadas em várias regiões dos EUA indicaram que o uso de espaçamentos entre $0,38 \mathrm{~m}$ e $0,50 \mathrm{~m}$ entre fileiras proporcionaram incremento de $5 \%$ na produtividade média, quando comparados com espaçamentos de $0,76 \mathrm{~m}$ (Farnham et al., 2002a e b).

Em Lavras/MG, a avaliação de dez genótipos de milho, em três espaçamentos $(0,45$; 0,70 e $0,90 \mathrm{~m}$ ), combinados em três populações de plantas $\left(55,70\right.$ e 90 mil plantas ha $\left.{ }^{-1}\right)$, demonstrou que o espaçamento entre linhas de $0,70 \mathrm{~m}$ proporcionou produtividade de grãos $17 \%$ superior ao espaçamento de $0,90 \mathrm{~m}$ e $33 \%$ superior ao espaçamento de $0,45 \mathrm{~m}$. Esse último espaçamento, combinado com 70.000 plantas ha $^{-1}$, proporcionou produção média $4,8 \%$ superior à obtida na combinação com 55.000 plantas ha ${ }^{-1}$, podendo-se considerar que, naquelas condições, a redução do espaçamento permitiu o aumento da população final para incremento em produtividade. Pode-se atribuir os resultados aos diferentes níveis de competição intra-específica estabelecidos para cada arranjo espacial de plantas. Diferenças significativas entre os genótipos também foram observadas, indicando adaptabilidade em função das características fenotípicas, dos espaçamentos e das densidades utilizadas (Sergio et al., 2002).

Em Lages/SC, a comparação de dois híbridos duplos das décadas de 70 e 80 , com arquitetura de folha aberta e grande número e comprimento de folhas, com um híbrido simples da década de 90, com folhas mais curtas, eretas e em menor número, submetidos ao mesmo espaçamento e às populações de 25, 50, 75 e 100.000 plantas ha-1, 
demonstrou que a resposta da produtividade de grãos ao incremento da população foi quadrática para todos os híbridos testados e o híbrido simples foi mais exigente, requerendo 85.000 plantas ha- $^{-1}$ para maximizar a produtividade de grãos. Na maior densidade, $5 \%$ das plantas dos híbridos duplos não produziram espigas, enquanto todas as plantas do híbrido simples produziram, em razão da sincronia no desenvolvimento floral, minimizando a natureza protândrica da planta em altas densidades. A arquitetura foliar ereta do híbrido simples favoreceu a interceptação de radiação, minimizando o sombreamento entre folhas, o que aumentou a disponibilidade de carboidratos durante a floração, sustentando o desenvolvimento das espigas e grãos em alta densidade (Sangoi et al., 2002).

A resposta dos genótipos à redução de espaçamento é variável em função das condições ambientais, pois híbridos de milho cultivados nos Estados Unidos, com 70.000 plantas ha ${ }^{-1}$, sob dois espaçamentos $(0,38$ e $0,76 \mathrm{~m})$, durante três safras consecutivas, semeados no mesmo dia e local em cada safra, apresentaram produtividades variáveis em função da oferta ambiental anual; entretanto, a adoção do menor espaçamento resultou em produtividade média 3\% superior (Farnham et al., 2002b).

Considerando o exposto, o propósito do presente trabalho foi avaliar o efeito da população e da distribuição espacial de plantas sobre o rendimento de grãos de três genótipos de milho com arquiteturas foliares distintas.

\section{Material e Métodos}

O experimento foi realizado entre os dias 20 de novembro de 2000 (Dia 1) e 10 de abril de 2001 (Dia 142), no município de Piracicaba/SP, com altitude de $540 \mathrm{~m}$, sendo apresentados os atributos climáticos do período nas Figuras 1 a 4.

O solo da área experimental é do tipo Nitossolo vermelho eutroférrico latossólico, textura argilosa.

Foram utilizados os seguintes híbridos, recomendados para a região do experimento, os quais apresentam boa tolerância às doenças de importância econômica para a época de semeadura do experimento: AG 1051: híbrido duplo, de arquitetura foliar aberta, ciclo semi-precoce (soma térmica $875^{\circ} \mathrm{C}$.dia) com recomendação de semeadura de 15 de outubro a 20 de dezembro e população

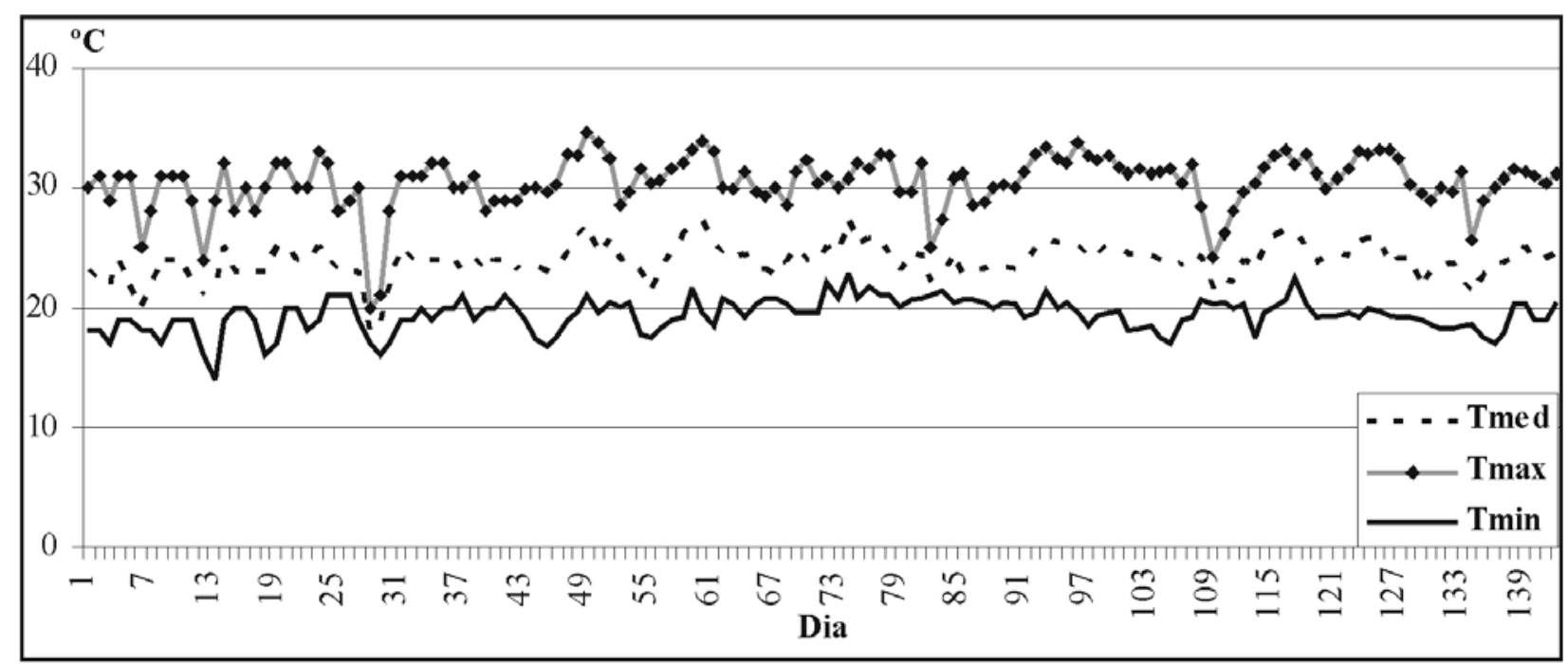

FIGURA 1. Valores diários das temperaturas médias $\left(\mathrm{T}_{\operatorname{med}}\right)$, máximas $\left(\mathrm{T}_{\max }\right)$ e mínimas $\left(\mathrm{T}_{\min }\right), \mathrm{em}^{\circ} \mathrm{C}$, registradas entre 20 de novembro de 2000 (Dia 1) e 10 de abril de 2001 (Dia 142). Piracicaba, SP. 


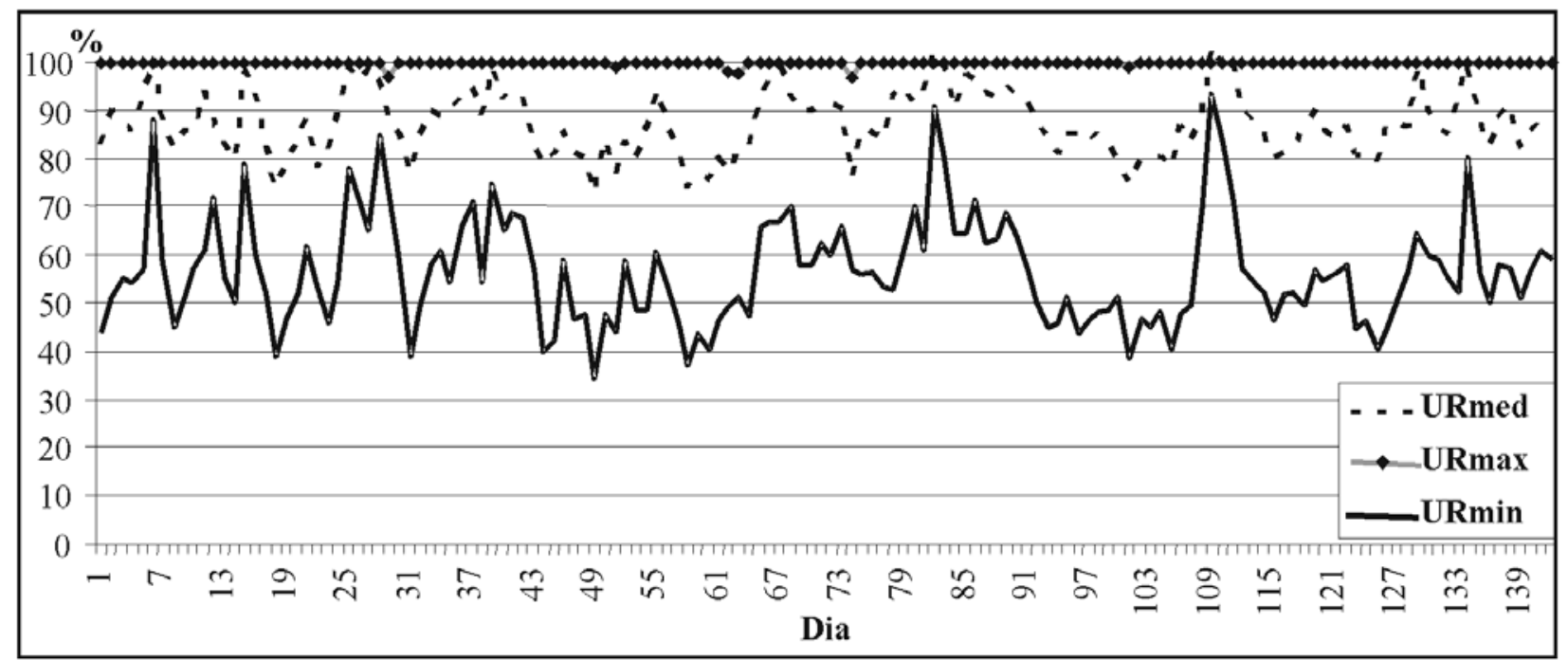

FIGURA 2. Valores diários das umidades relativas médias $\left(U_{\text {med }}\right)$, máximas $\left(U_{\text {max }}\right)$ e mínimas $\left(U_{\text {min }}\right)$, em $\%$, registradas entre 20 de novembro de 2000 (Dia 1) e 10 de abril de 2001 (Dia 142). Piracicaba, SP.

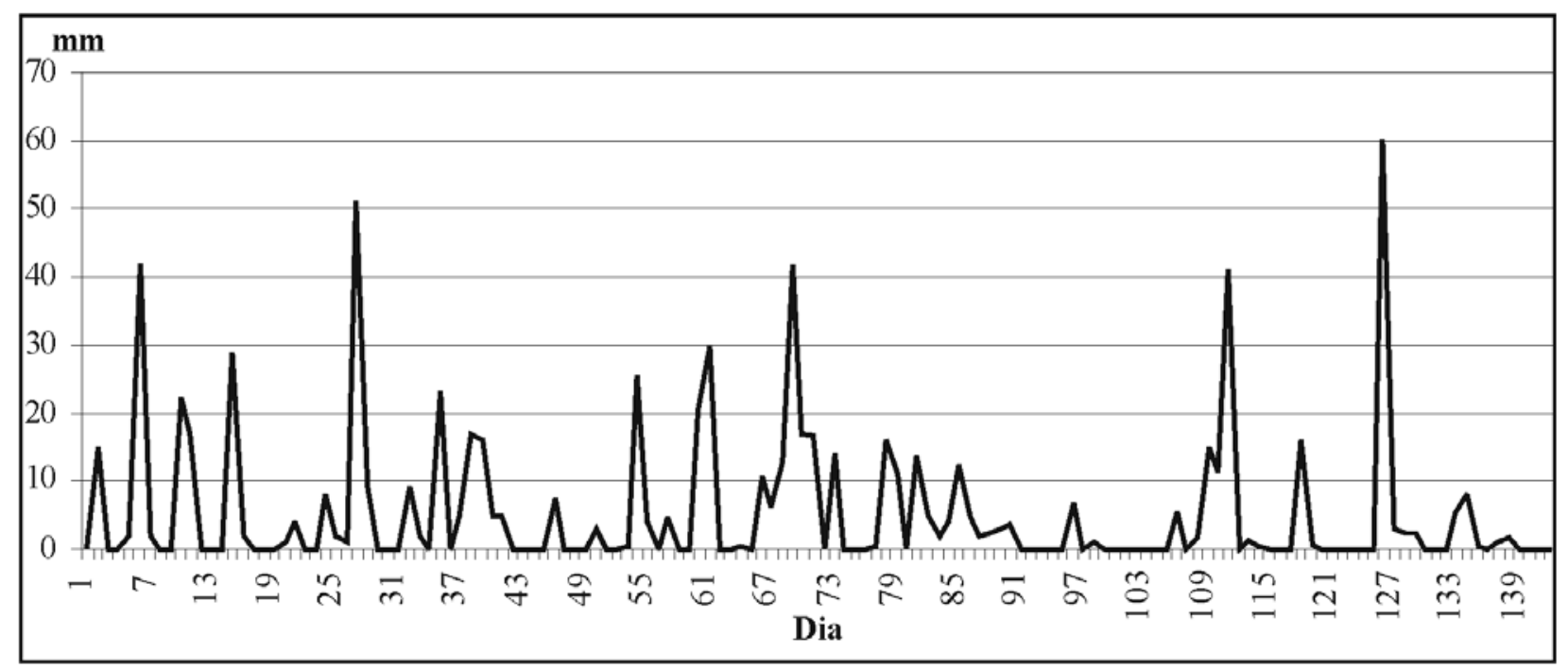

FIGURA 3. Valores diários de precipitação, em mm, registradas entre 20 de novembro de 2000 (Dia 1) e 10 de abril de 2001 (Dia 142). Piracicaba, SP.

final de 50.000 plantas ha $^{-1}$; AG 7575: híbrido simples modificado, de arquitetura foliar semi-ereta, ciclo precoce (soma térmica $837^{\circ} \mathrm{C}$.dia) com recomendação de semeadura de 20 de setembro a 20 de fevereiro e população final de 55.000 plantas ha $^{-1}$; DKB 911: híbrido simples, de arquitetura foliar ereta, ciclo precoce (soma térmica $830^{\circ} \mathrm{C}$.dia), com recomendação de semeadura de 1 de outubro a 30 de novembro e população final de 55.000 a 60.000 plantas ha ${ }^{-1}$.

Foram estabelecidos dezoito tratamentos, com três repetições, distribuídos em blocos ao acaso, em fatorial de $2 \times 3 \times 3$, resultantes da combinação entre dois espaçamentos $(0,40$ e $0,80 \mathrm{~m})$, três densidades populacionais (30; 60 e 90 mil plantas por hectare) e os três genótipos. 


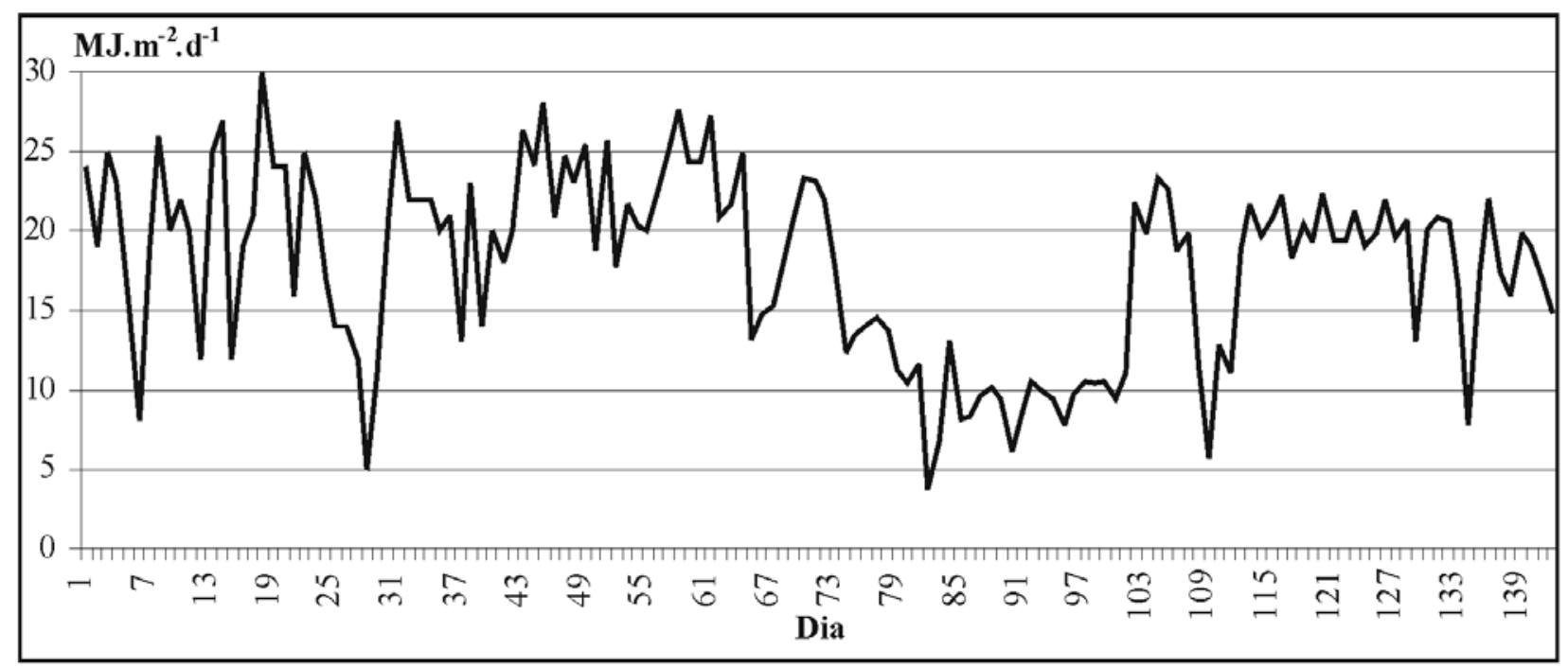

FIGURA 4. Valores diários da radiação global, em $\mathrm{MJ} \mathrm{m}^{-2} \mathrm{~d}^{-1}$, registradas entre 20 de novembro de 2000 (Dia 1) e 10 de abril de 2001 (Dia 142). Piracicaba, SP.

A semeadura foi realizada manualmente, segundo a densidade de sementes apresentada na Tabela 1, em parcelas com $12 \mathrm{~m}^{2}$. No espaçamento de $0,80 \mathrm{~m}$, cada parcela se constituiu de cinco linhas de sete metros de comprimento, sendo consideradas para as avaliações as três linhas centrais, excluindo-se um metro de cada extremidade. No espaçamento de $0,40 \mathrm{~m}$, cada parcela se constituiu de cinco linhas de doze metros de comprimento, sendo consideradas para as avaliações as três linhas centrais, excluindo-se um metro de cada extremidade.

A adubação de semeadura, com $30 \mathrm{~kg}$ de nitrogênio, $80 \mathrm{~kg}$ de $\mathrm{P}_{2} \mathrm{O}_{5}$ e $50 \mathrm{~kg}$ de $\mathrm{K}_{2} \mathrm{O}$ por hectare, foi realizada manualmente, objetivando produtividade acima de $8.000 \mathrm{~kg}$ por hectare, ajustando-se a distribuição do fertilizante para cada espaçamento utilizado.
O controle de plantas daninhas foi realizado na pré- emergência, com aplicação dos princípios ativos atrazina e metolachlor, logo após a semeadura.

Conduzido sob sistema de irrigação por aspersão convencional, cada tratamento recebeu 90 $\mathrm{kg}$ por hectare de nitrogênio em cobertura, divididos em duas aplicações quando as plantas apresentavam quatro e oito folhas totalmente expandidas.

Para o controle de Spodoptera frugiperda, foi suficiente uma aplicação de clorpirifós.

A partir da emergência das plantas, foi determinado, em cada tratamento, o número total de folhas, com suas respectivas datas de extensão total, até a emissão da folha bandeira, seguida do florescimento masculino. Baseando-se na consistência

TABELA 1. Número de sementes distribuídas por metro linear para obtenção de três populações de plantas em dois espaçamentos no experimento realizado em Piracicaba, SP.

\begin{tabular}{cccc}
\hline \multirow{2}{*}{ Espaçamento entre linhas $(\mathbf{m})$} & \multicolumn{3}{c}{ População de Plantas } \\
\cline { 2 - 4 } & $\mathbf{3 0 . 0 0 0}$ & $\mathbf{6 0 . 0 0 0}$ & $\mathbf{9 0 . 0 0 0}$ \\
\hline 0,4 & 1,2 & 2,4 & 3,6 \\
0,8 & 2,4 & 4,8 & 7,2 \\
\hline
\end{tabular}


dos grãos, foram registradas as datas de ocorrência das fases de grãos pastosos e grãos farináceos. A data da maturidade fisiológica foi definida pela formação da camada negra dos grãos.

No florescimento, foram abertas trincheiras, cujas seções obedeceram aos limites intermediários de área e volume de exploração de solo entre as fileiras e entre as plantas da fileira na profundidade de um metro, para coleta de plantas de cada um dos genótipos, nos espaçamentos de $0,4 \mathrm{e}$ 0,8 m e populações de 30.000 e 90.000 plantas ha $^{-1}$. Após a lavagem das raízes, foram determinados os pesos frescos e secos, em estufa a $72^{\circ} \mathrm{C}$ por 72 horas, do pendão, do colmo, das folhas, das espigas e das raízes.

No florescimento masculino, foram medidos o diâmetro dos colmos (do solo a $1,5 \mathrm{~m}$ de altura), a altura das espigas (do solo à base do pedúnculo da espiga) e altura das plantas (do solo à base da folha "bandeira"). Na colheita, foram determinados o número de grãos por fileira, número de fileiras por espigas e comprimento das espigas.

Para todas as determinações descritas, foram consideradas dez plantas representativas de cada parcela.

A colheita foi manual, no dia 10/04/ 2001, recolhendo-se todas as espigas da área útil da parcela e determinados o teor de água dos grãos, por método gravimétrico, e a produtividade $\left(\mathrm{kg} \mathrm{ha}^{-1}\right) \mathrm{a}$ $13 \%$ b.u.

Foi realizada a análise de variância das variáveis produtividade de grãos, altura de plantas, comprimento de espiga, diâmetro de colmo, número de grãos por fileira e número de fileiras por espiga. O efeito da distribuição das plantas na área sobre a variável de interesse, em cada material genético, para uma densidade populacional específica de plantas, foi avaliado utilizando testes t para contrastes (Montgomery, 1997). O efeito do genótipo em cada combinação, arranjo versus população de plantas, foi avaliado pelo mesmo procedimento.
Foi calculado o coeficiente de correlação de Pearson (r) entre as variáveis altura de planta, diâmetro de colmo, comprimento de espiga, número de grãos por fileira e número de fileiras por espiga. A significância dos coeficientes de correlação foi avaliada utilizando teste $t$.

\section{Resultados e Discussão}

Baixa densidade de plantas reduz a interceptação da radiação solar por área, favorecendo a produção de grãos por planta, mas reduzindo a produtividade por área (Sangoi, 2001). Com o aumento da população de plantas, há redução no tamanho das espigas, diminuindo também seu índice por planta; entretanto, há compensação na produção, pelo aumento do número de plantas por área. Por outro lado, o adensamento excessivo incrementa a competição intra-específica, o que estimula a dominância apical, aumentando a esterilidade feminina e limitando a produção de grãos por área (Fornasieri Filho, 1992). O comportamento descrito pode ser observado na Figura 5, o pela qual se percebe que a produção de grãos $\left(\mathrm{kg} \mathrm{ha}^{-1}\right)$ aumenta linearmente com o aumento da população de plantas, até um

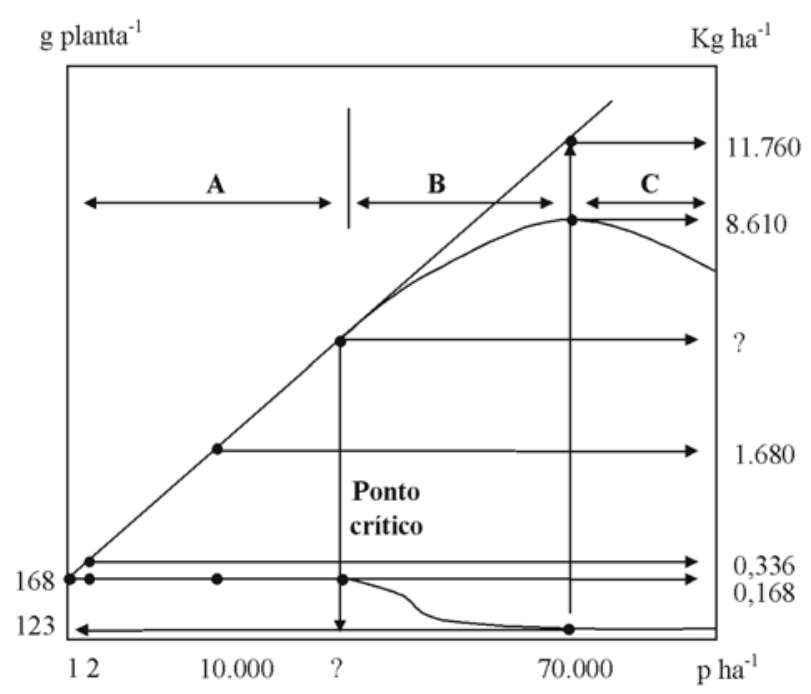

FIGURA 5. Variação teórica da produção por unidade de planta $\left(\mathrm{g} \mathrm{pl}^{-1}\right)$ e por unidade de área $\left(\mathrm{kg} \mathrm{ha}^{-1}\right)$ em função da população (Dourado Neto et al., 2001). 
ponto denominado "ponto crítico", o qual varia entre 30 e 90.000 plantas ha- $^{-1}$, pelo fato de a produção de grãos por planta permanecer constante. Nessa faixa de população, não há competição intra-específica. Acima da população crítica, devido à competição intra-específica, a produção por planta decresce, determinando um ponto de máxima produção por unidade de área (Dourado Neto et al., 2001).
A descrição dos estádios fenológicos (Figura 6) indicou que, durante a fase vegetativa, não houve diferença de ciclo.

As alturas de plantas (Figura 7) apresentaram diferenças significativas entre espaçamentos (E), genótipos (G), e populações $(P)$, bem como para suas interações: GxE, ExP, GxP e GxExP, sendo o erro padrão da diferença entre médias de $0,653 \mathrm{~cm}$.

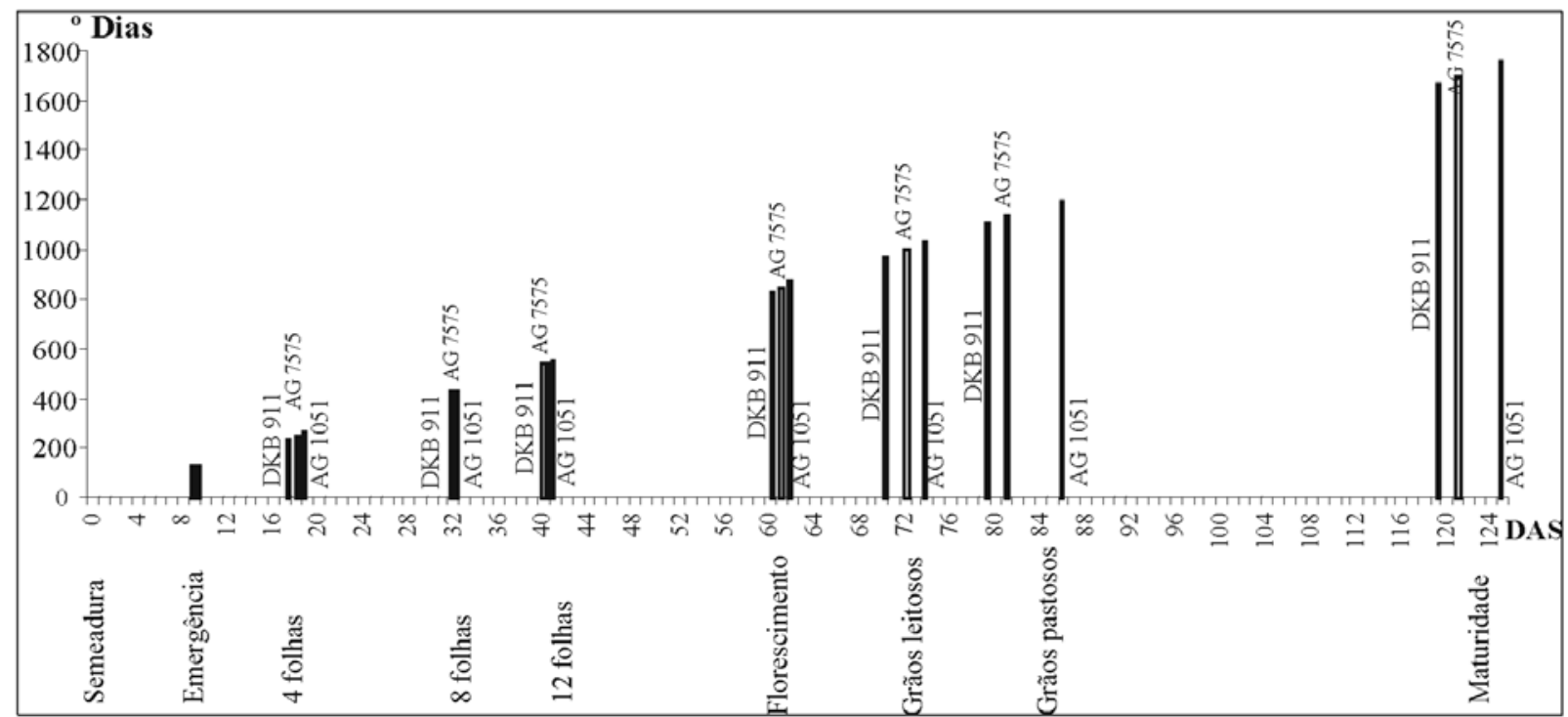

FIGURA 6. Dias após a semeadura (DAS), fenologia e graus-dia (GD, considerando temperatura basal $10^{\circ} \mathrm{C}$ ) referentes aos três genótipos (AG 1051, AG 7575 e DKB 911).

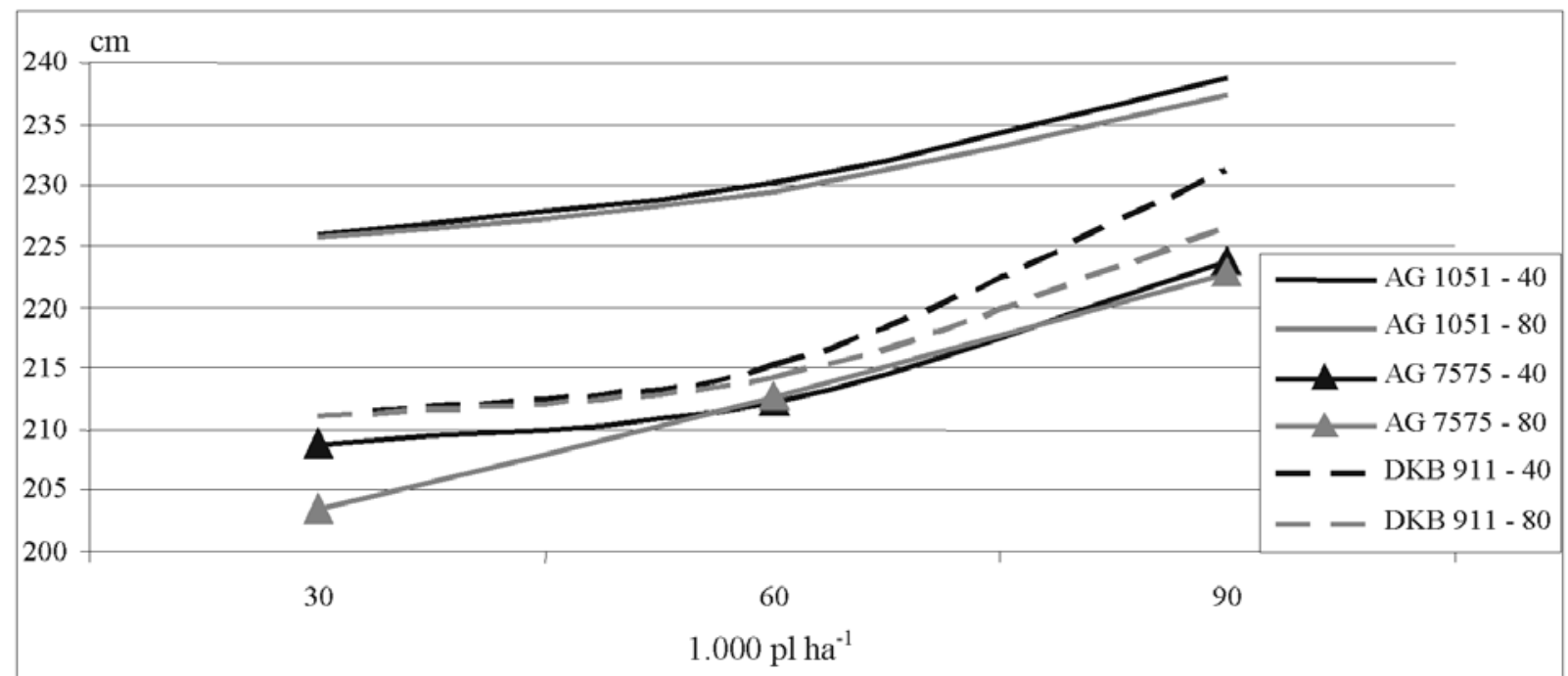

FIGURA 7. Altura média $(\mathrm{cm})$ de plantas de milho referente aos diferentes tratamentos. $\mathrm{r}^{2}=0,996 ; \mathrm{CV}=0,36 \%$; Altura média da planta $=220,39 \mathrm{~cm}$. 
A altura do genótipo AG 1051 foi superior à dos genótipos AG 7575 e DKB 911, independente dos espaçamentos e populações utilizados. A altura do genótipo DKB 911 foi superior à do genótipo AG 7575, sob todos os arranjos espaciais, sendo essas diferenças associadas à genética dos híbridos.

O DKB 911 apresentou maior altura de plantas na população mais elevada e no menor espaçamento, pois o espaçamento de $0,40 \mathrm{~m}$, quando comparado com o de $0,80 \mathrm{~m}$, propicia menor competição intra-específica por água e nutrientes. Nas populações de 30.000 e 60.000 plantas ha $^{-1}$, não se observou o efeito do arranjo espacial para altura da planta.

O AG 1051 e o AG 7575 apresentaram comportamento semelhante ao DKB $911 \mathrm{em}$ alta população, porém, em menores populações não houve resultado consistente, provavelmente por se tratarem de genótipos heterogêneos.

De maneira geral, exceto para o AG 1051 , no espaçamento de $0,80 \mathrm{~m}$, no contraste de $30.000 \times 60.000$ plantas ha $^{-1}$, a altura de planta foi tanto maior quanto maior foi a população para os três genótipos, nos dois espaçamentos utilizados, devido ao efeito combinado da competição intraespecífica por luz, com conseqüente estímulo da dominância apical das plantas, conforme relatou Sangoi (2001).

Para o diâmetro de colmos (Figura 8), o erro padrão da diferença entre médias foi 0,019 $\mathrm{cm}$. Independentemente da população e do espaçamento entre plantas, o AG 7575 foi o que apresentou o menor diâmetro de colmo, enquanto que o maior diâmetro foi observado no AG 1051.

Em altas populações, independentemente do genótipo, o diâmetro do colmo aumentou com a redução do espaçamento, mas, para menores populações, foi observada redução do diâmetro de colmo sob a redução do espaçamento. Por outro lado, a redução da população de plantas, independentemente dos genótipos e espaçamentos utilizados, resultou em aumento no diâmetro do colmo.

Para o comprimento de espiga (Figura 9), o erro padrão da diferença entre médias foi 0,070 $\mathrm{cm}$. O AG 1051 apresentou maior comprimento de

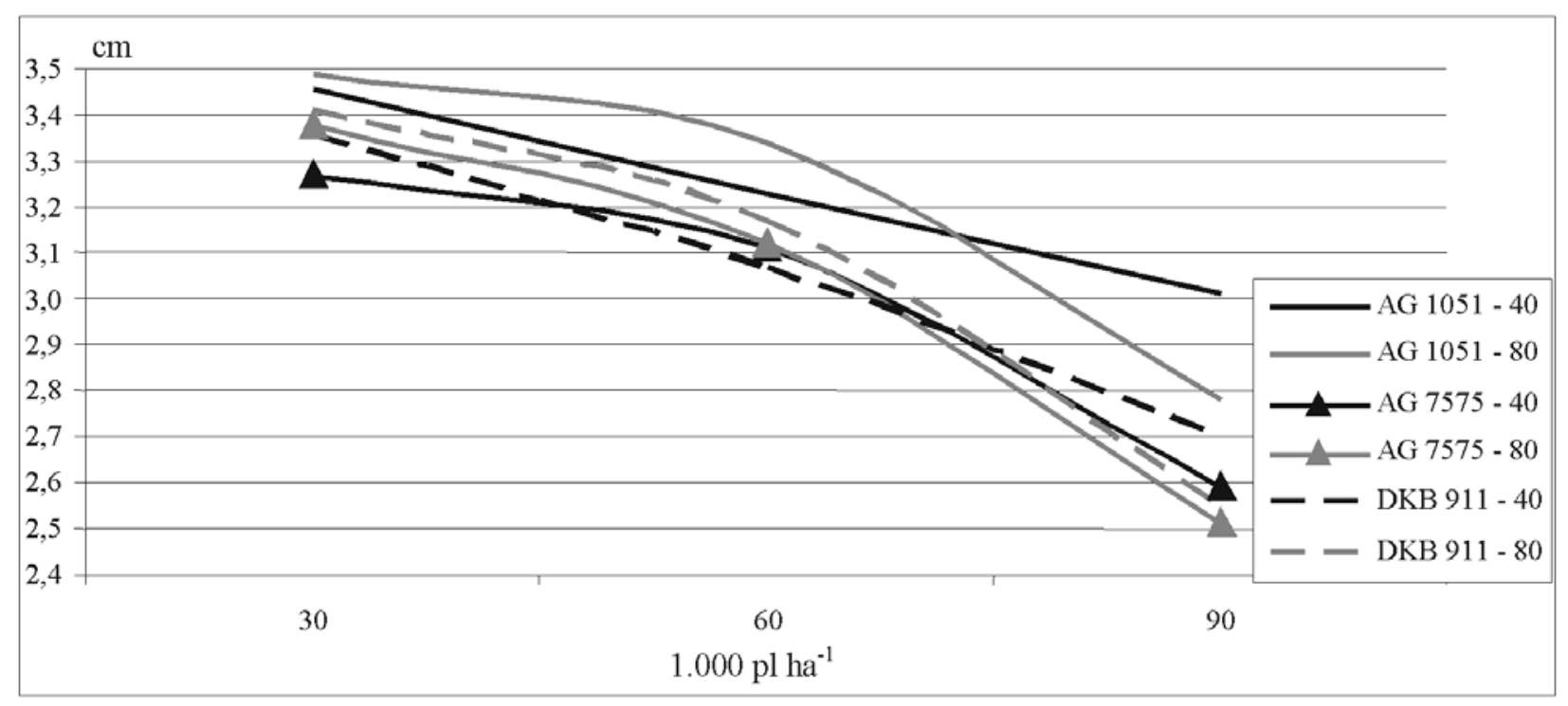

FIGURA 8. Diâmetro médio de colmo $(\mathrm{cm})$ de plantas de milho referente aos diferentes tratamentos. $\mathrm{r}^{2}=$ 0,997; CV = 0,74\%; Diâmetro médio do Colmo = 3,08 cm. 
espiga nas menores populações, independentemente da distribuição, mas, em alta população, ocorreu o inverso, quando comparado ao AG 7575. Com 90.000 plantas ha $^{-1}$, o AG 1051 apresentou maior comprimento de espiga, quando comparado com o DKB 911, no espaçamento de $0,80 \mathrm{~m}$. No espaçamento de $0,40 \mathrm{~m}$, não houve diferença significativa.

O AG 7575, na população de 30.000 plantas ha-1 ${ }^{-1}$ apresentou menor comprimento de espiga, quando comparado com o DKB 911, independentemente do espaçamento. $\mathrm{O}$ inverso ocorreu em 90.000 plantas ha-1. Já em 60.000 plantas ha $^{-1}$, o AG 7575 apresentou menor comprimento de espiga no espaçamento de $0,40 \mathrm{~m}$. O inverso aconteceu no espaçamento de $0,80 \mathrm{~m}$.

Nas populações de 30.000 e 60.000 plantas ha ${ }^{-1}$, para todos os genótipos, houve aumento do comprimento de espigas pela redução do espaçamento de $0,80 \mathrm{~m}$ para $0,40 \mathrm{~m}$, provavelmente devido aos efeitos da distribuição de plantas. Por outro lado, ocorreu o inverso para todos os genótipos sob a população de 90.000 plantas ha ${ }^{-1}$, condição em que a competição intra-específica por água, nutrientes e luz superou os efeitos do melhor arranjo espacial entre as plantas.

À exceção do AG 7575, no espaçamento de $0,80 \mathrm{~m}$ e contraste $30.000 \times 60.000$ plantas ha ${ }^{-1}$, houve aumento significativo no comprimento de espigas para todos os genótipos e espaçamentos, para as menores populações de plantas.

Considerando-se os três genótipos e os dois espaçamentos $(0,40$ e $0,80 \mathrm{~m})$, observou-se uma tendência geral de diminuição da massa de matéria seca de raiz por unidade de planta com o aumento da população de 30.000 para 90.000 plantas ha-1 (Figura 10), sendo a mesma tendência observada para as massas de matéria seca de parte aérea (Figura 11) e total (Figura 12).

A quantidade relativa de raiz no florescimento, em relação à massa de matéria seca total, diminuiu de $26 \%$ para $19 \%$ com o aumento da população de 30.000 para 90.000 plantas ha h $^{-1}$ (Figuras 12 e 13). Já a parte aérea aumentou de $74 \%$ para $81 \%$ (Figura 14), o que explica, parcialmente,

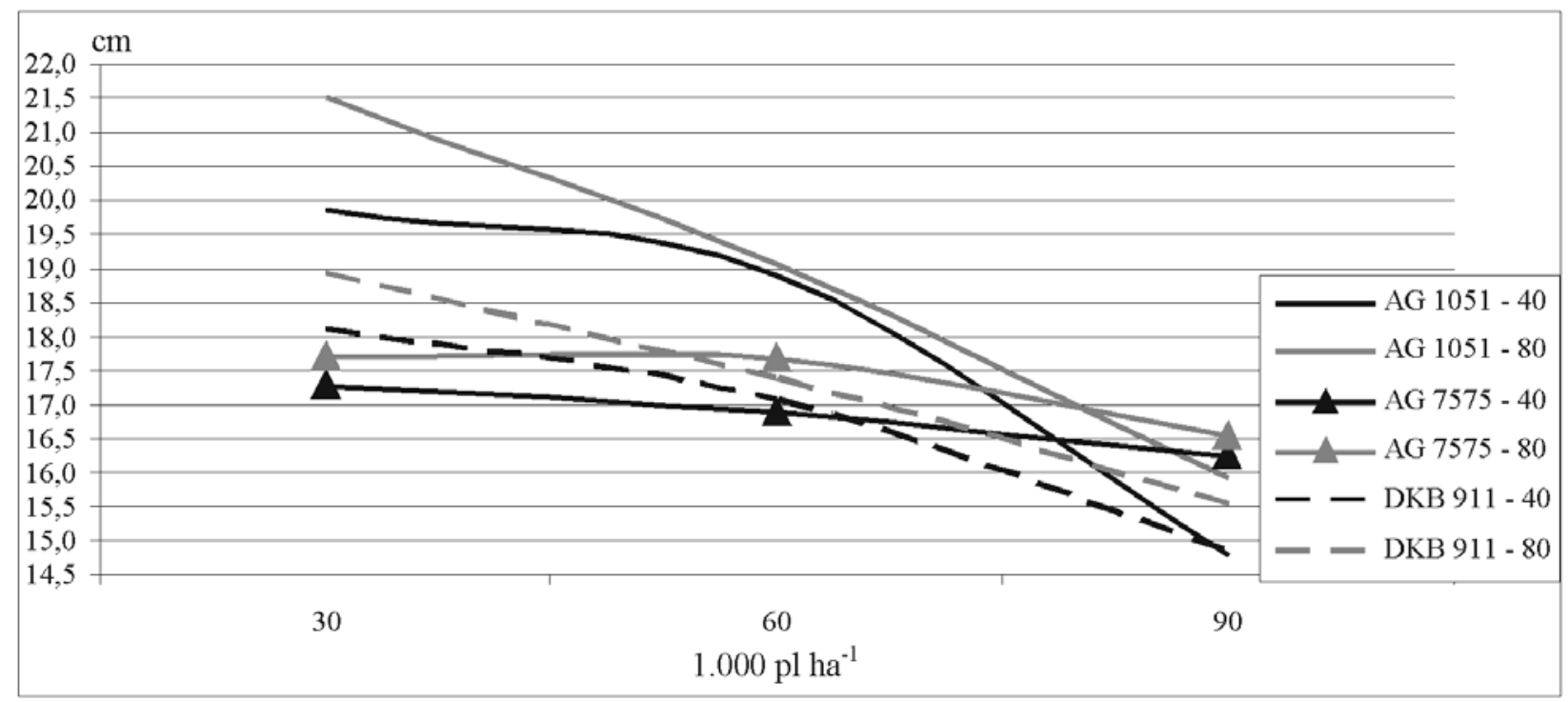

FIGURA 9. Comprimento $(\mathrm{cm})$ médio de espiga de plantas de milho referente aos diferentes tratamentos. $\mathrm{r}^{2}$ $=0,998 ; \mathrm{CV}=0,49 \%$; Comprimento médio da espiga $=17,46 \mathrm{~cm}$. 
porque populações elevadas apresentaram maior porcentagem de quebramento de colmos e de acamamento de plantas.

Se computados todos os genótipos e arranjos, pode-se verificar que, quando a população foi triplicada, a produção de massa de matéria seca total da parte aérea por unidade de planta se reduziu 1,6 vez, ou seja, a produção, por unidade

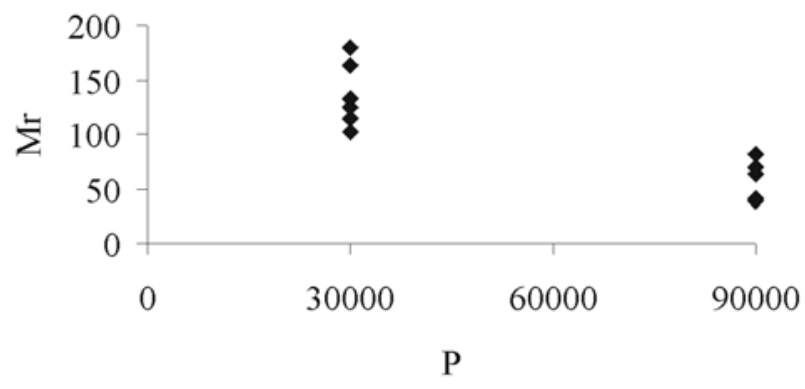

FIGURA 10. Relação entre massa de matéria seca de raiz $\left(\mathrm{Mr}, \mathrm{g} \mathrm{pl}^{-1}\right)$ e população de plantas (plantas ha ${ }^{-1}$ ) no florescimento.

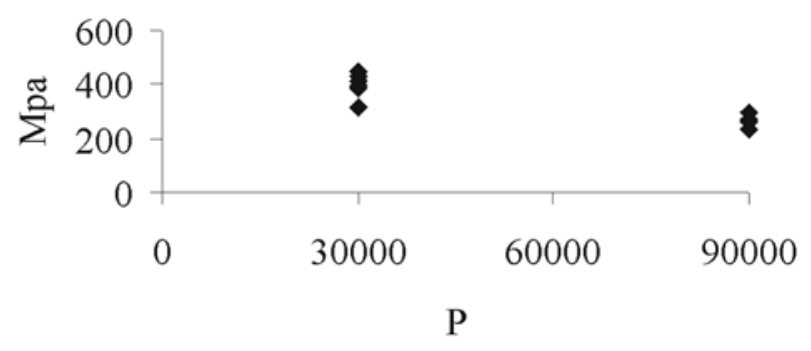

FIGURA 11. Relação entre massa de matéria seca de parte aérea $\left(\mathrm{Mpa}, \mathrm{g} \mathrm{pl}^{-1}\right)$ e população de plantas $\left(\right.$ plantas ha ${ }^{-1}$ ) no florescimento.

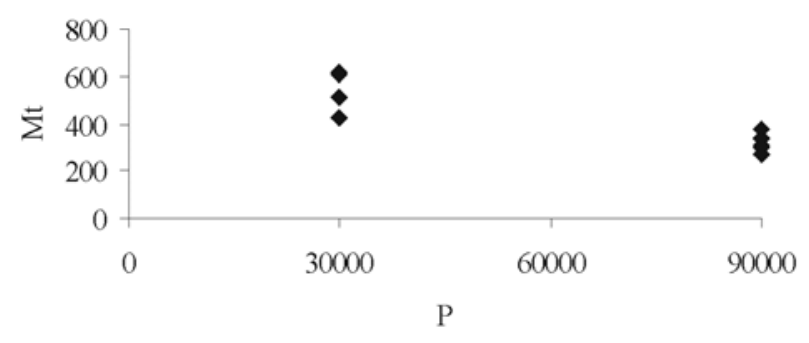

FIGURA 12. Relação entre massa de matéria seca total $\left(\mathrm{Mt}, \mathrm{g} \mathrm{pl}^{-1}\right)$ e população de plantas (plantas ha- ${ }^{-1}$ ) no florescimento. 30000pl ha-1
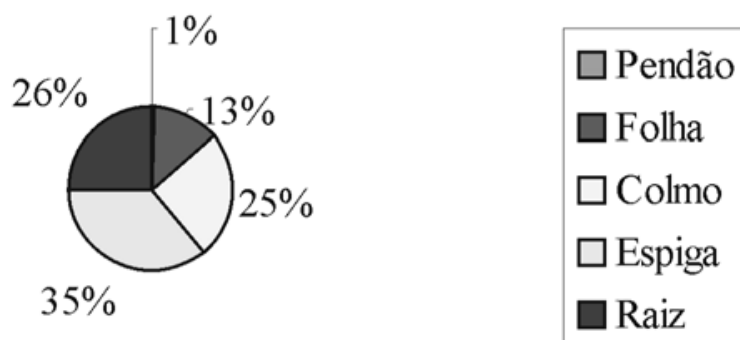

FIGURA 13. Quantidade relativa de massa de matéria seca de raiz e de parte aérea na colheita da cultura de milho referente à menor população.

de área, para esse caso específico, aumentou $82 \%$. Analogamente, pode-se explicar o fato de a população ser um dos principais fatores de produção na cultura do milho, pois a produção de grãos por unidade de área aumentou devido ao aumento da população ter ocorrido numa proporção superior à queda de produção por unidade de planta.

Em termos relativos, o aumento de população alterou a produção dos diferentes órgãos, variando, respectivamente, para pendão, folha, colmo, espiga e raiz,de $1 \%, 13 \%, 25 \%, 35 \%$ e $26 \%$ (Figura 13) para 1\%, 17\%, 27\%, 36\% e 19\% (Figura 14). Em valores absolutos, observou-se a mesma tendência de diminuição de produção de massa de matéria seca por unidade de planta com o aumento da população (Figura 15).

\section{0pl ha-1}
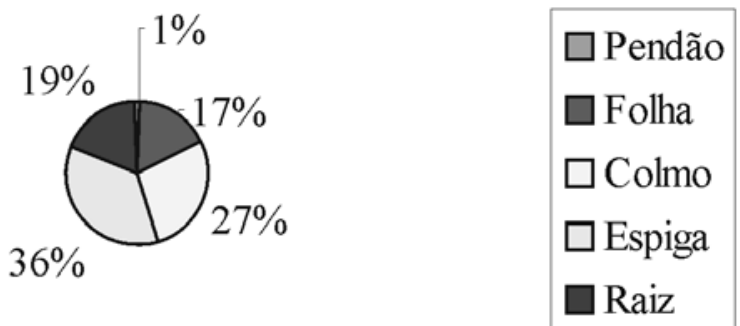

FIGURA 14. Quantidade relativa de massa de matéria seca de raiz e de parte aérea na colheita da cultura de milho referente à maior população. 


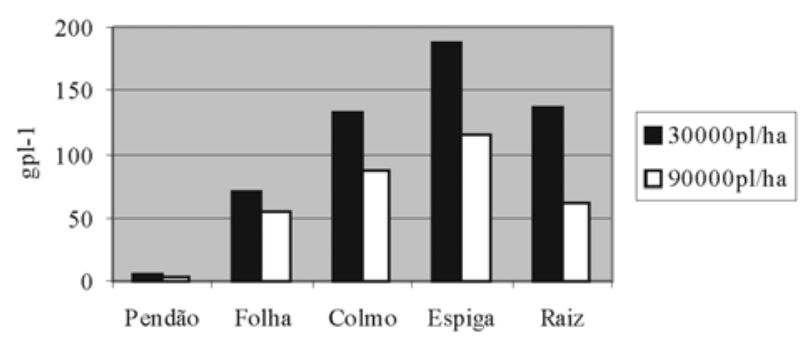

FIGURA 15. Massa de matéria seca $\left(\mathrm{g} \mathrm{pl}^{-1}\right)$ de pendão, folha, colmo, espiga e raiz para a combinação dos diferentes genótipos (AG 1051, AG 7575 e DKB 911) e espaçamentos $(0,40$ e $0,80 \mathrm{~m})$ para alta (30.000 plantas ha-1) e baixa (90.000 plantas ha-1) população.

O erro padrão da diferença entre médias para o número de grãos por fileira (Figura 16) foi 0,959 , sendo que o AG 1051 apresentou maior número de grãos por fileira em relação ao $\mathrm{AG} 7575$ somente nas combinações entre 30.000 e 60.000 plantas ha ${ }^{-1}$ e $0,40 \mathrm{~m}$ e $0,80 \mathrm{~m}$, respectivamente. $\mathrm{Na}$ população de 90.000 plantas ha-1 ${ }^{-1}$, nos dois espaçamentos, ocorreu o inverso.

Em relação ao DKB 911, o AG 1051 comportou-se de maneira semelhante, porém não houve diferenças na maior população, nos dois espaçamentos. Em geral, o número de grãos por fileira no AG 7575 foi menor que no DKB 911, independentemente do espaçamento e da população.

A redução do espaçamento de $0,80 \mathrm{~m}$ para $0,40 \mathrm{~m}$, de maneira geral, não influenciou o número de grãos por fileira, nas três populações, exceto para o AG 1051, em que houve redução desse componente, provavelmente devido à variabilidade genética do híbrido.

As menores populações de plantas proporcionaram aumento significativo no número de grãos por fileira para todos os genótipos e espaçamentos, exceto nos contrastes de 30.000x60.000 do AG 7575, nos dois espaçamentos.

O erro padrão da diferença entre médias para fileiras de grãos por espiga foi 0,361. De maneira geral, o AG 1051 apresentou maior número de fileiras do que o AG 7575, em todas as combinações. Em relação ao DKB 911, comportou-se de maneira semelhante somente nas combinações de $0,40 \mathrm{~m}$ x 60.000 plantas ha ${ }^{-1}$ e $0,80 \mathrm{~m}$ x 90.000 plantas ha-1. Por outro lado, houve uma tendência de ocorrer maior número de fileiras no DKB 911

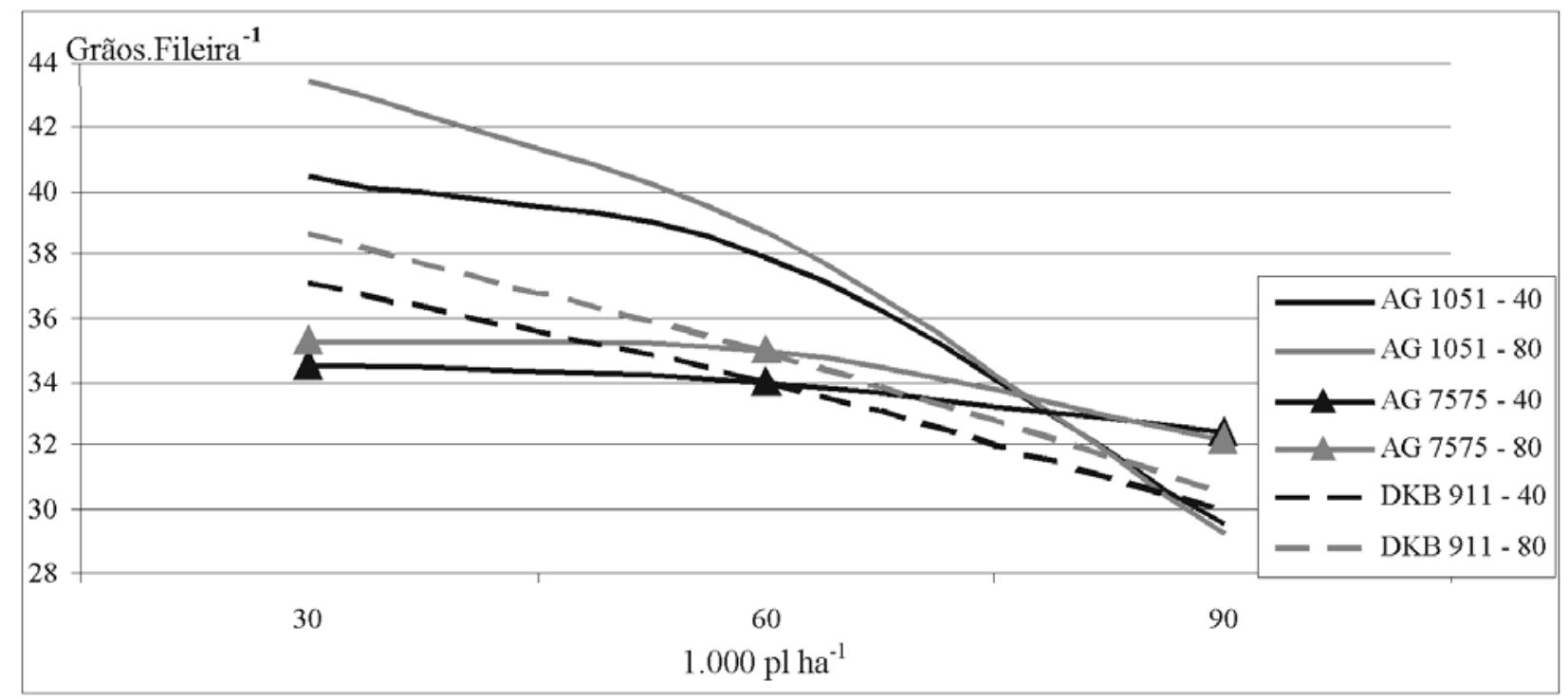

FIGURA 16. Número médio de grãos por fileira referente aos diferentes tratamentos. $\mathrm{r}^{2}=0,945, \mathrm{CV}=$ $3,37 \%$; Número médio de grãos por fileira $=34,87$. 
em relação ao AG 7575, em todos os tratamentos (Figura 17).

A redução do espaçamento promoveu aumento significativo do número de fileiras por espigas para o DKB 911, sob 30.000 plantas ha-1 $^{-1}$, bem como para o AG 1051 na população de 60.000 plantas ha-1 ${ }^{-1}$ Por outro lado, esse último híbrido teve seu número de fileiras por espiga reduzido na combinação de $0,40 \mathrm{~m}$ x 90.000 plantas ha-1 $^{-1}$. Observou-se que, possivelmente, a composição genética tropical do AG 1051, que lhe confere porte alto, folhas largas, compridas e angulação com o colmo próxima de $90^{\circ}$, propiciou a intensificação da competição intra-específica por luz, a partir da décima segunda folha, principalmente na condição de espaçamento reduzido, fato que pode explicar a redução do número de fileiras por espiga, observada no experimento, nessa condição.

A análise de correlação entre os componentes de produção demonstrou que, para o $\mathrm{AG}$ 1051, quanto maior a altura das plantas, menor foi o diâmetro do colmo, o comprimento da espiga e o número de grãos por fileira. $\mathrm{O}$ aumento no diâmetro de colmo, por sua vez, proporcionou aumento no comprimento da espiga e no número de grãos por fileira, bem como o comprimento da espiga correlacionou-se positivamente com número de grãos por fileira. Por outro lado, altura de planta, diâmetro do colmo, comprimento de espiga e grãos por fileira não influenciaram o número de fileiras por espiga.

Análise de correlação entre os componentes de produção referente ao AG 7575 demonstrou, da mesma forma, que o aumento de altura de planta correlacionou-se positivamente com maiores diâmetros de colmo, comprimentos de espiga e grãos por fileira. Maiores diâmetros de colmo influenciaram o aumento do comprimento de espiga, grãos por fileira e de fileiras por espiga, enquanto espigas mais compridas apresentaram maior número de grãos por fileira e de fileiras por espiga. Não houve correlação entre número de grãos por fileira e número de fileiras por espiga.

O DKB 911 foi o que apresentou todas as correlações positivas entre os componentes de produção mencionados, possivelmente devido à sua uniformidade genética.

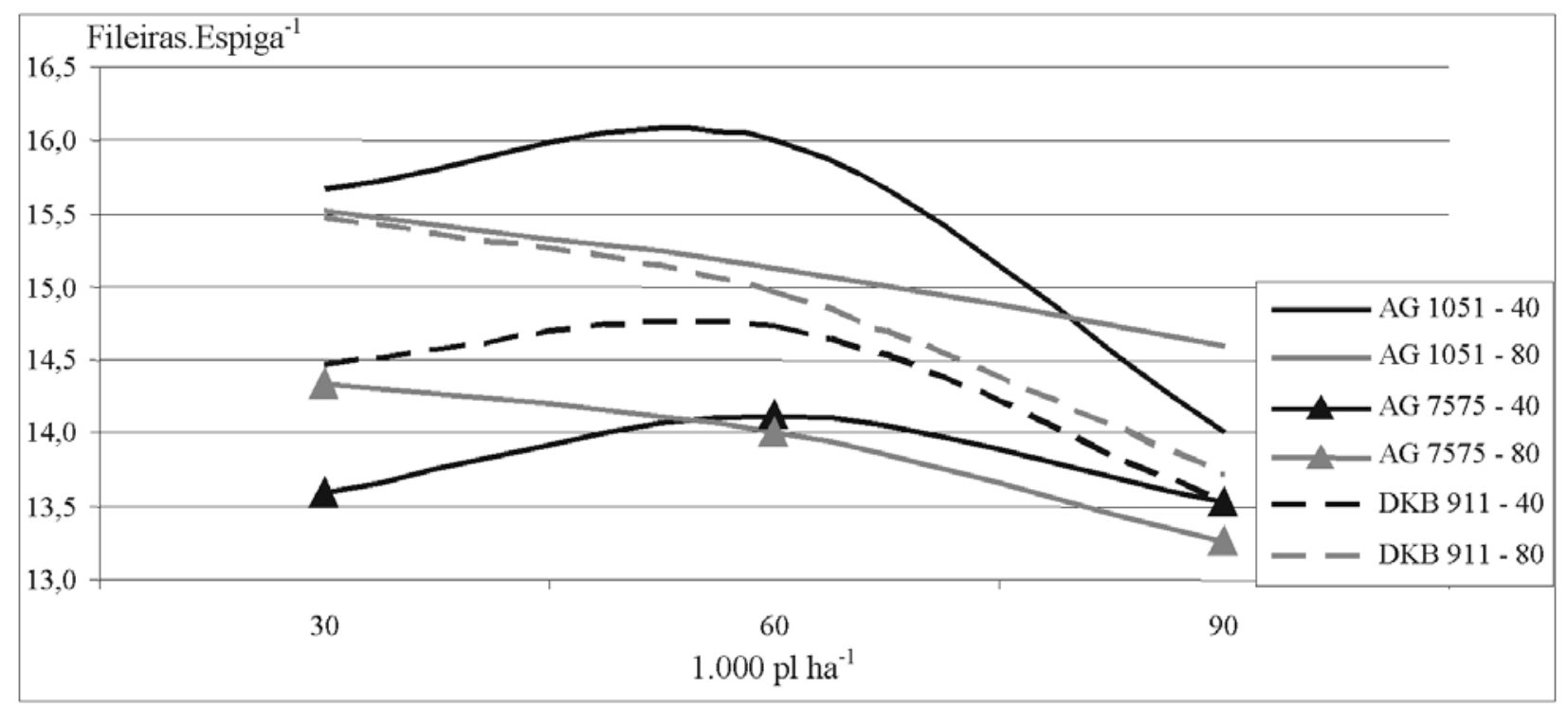

FIGURA 17. Número médio de fileiras de grãos por espiga de milho referente aos diferentes tratamentos. $\mathrm{r}^{2}$ $=0,867 ; \mathrm{CV}=3,04 \%$; Número médio de fileiras de grãos por espiga de milho $=14,54$. 
A maior altura de plantas e o menor diâmetro de colmo ocorreram sob a maior população, relação esta que inverteu-se à medida em que a população diminuiu.

Não houve aumento do número de fileiras por espiga em função do aumento do número de grãos por fileira, embora este tenha sido maior nas menores populações.

Em todos os genótipos, a maior altura de planta e o maior comprimento de espiga ocorreram sob a maior população, relação esta que inverteu-se à medida em que a população diminuiu.

Para todos os genótipos, o maior diâmetro de colmo e o maior comprimento de espiga ocorreram sob a menor população, relação esta que inverteu-se à medida em que a população aumentou.

O erro padrão da diferença entre médias de produtividade de grãos (Figura 18) foi 0,59258 t ha-1, sendo o AG 1051 superior ao AG 7575 na combinação do espaçamento de $0,40 \mathrm{~m}$ e 90.000 plantas ha $^{-1}$, enquanto o AG 7575 e o AG 1051 foram superiores ao DKB 911, na combinação entre o espaçamento de $0,80 \mathrm{~m}$ e 90.000 plantas ha $^{-1}$. Para os demais contrastes entre genótipos, sob diferentes combinações entre espaçamento e população, não houve diferença.

A redução do espaçamento de $0,80 \mathrm{~m}$ para $0,40 \mathrm{~m}$ afetou positivamente a produtividade de grãos somente para o AG 1051 (folhas abertas), sob alta população. Por outro lado, a redução do espaçamento não proporcionou diferenças significativas na produtividade dos híbridos de arquiteturas foliares semi-ereta e ereta, em nenhuma das populações avaliadas.

A produtividade do genótipo DKB 911 foi crescente à medida em que a população elevouse, independentemente do espaçamento utilizado. A mesma tendência ocorreu com os outros genótipos, exceto para o AG 1051, no espaçamento de 0,40 $\mathrm{m}$ e para o AG 7575, no espaçamento de $0,80 \mathrm{~m}$, em que a produtividade sob 60.000 plantas ha- $^{-1}$ foi maior que com a população de 90.000 plantas ha $^{-1}$.

Os resultados foram obtidos para a faixa de população de 30.000 a 90.000 plantas ha $^{-1}$ em ambiente onde não houve limitação de água e

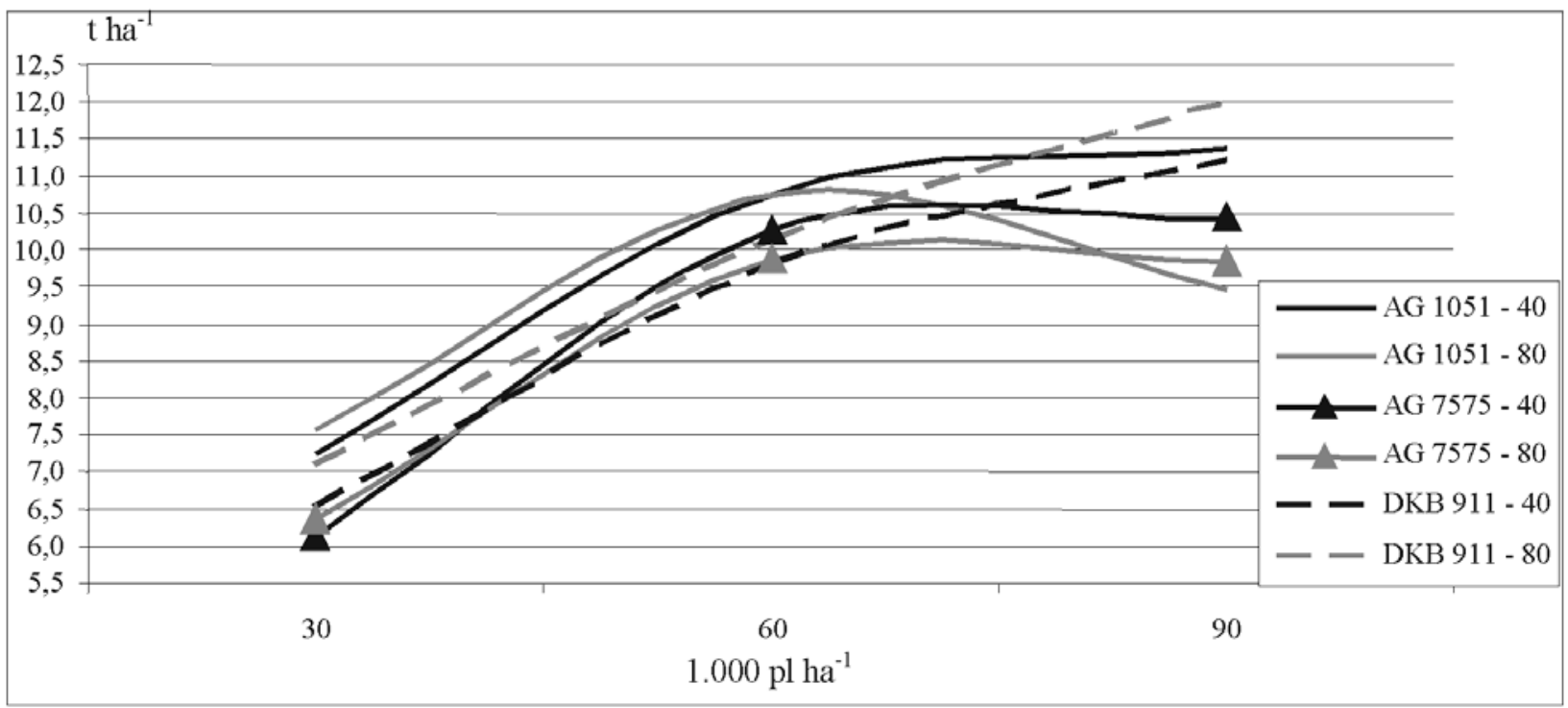

FIGURA 18. Produtividade média de grãos $\left(\mathrm{t} \mathrm{ha}^{-1}\right)$ referente aos diferentes tratamentos. $\mathrm{r}^{2}=0,912 . \mathrm{CV}=$ 7,83. produtividade média de grãos $=9.270,92 \mathrm{t} \mathrm{ha}^{-1}$. 
nutrientes, e sugerem que o decréscimo de produtividade poderia ser observado em população superior a 90.000 plantas ha $^{-1}$, no caso genótipo de arquitetura foliar ereta (DKB 911), principalmente.

O menor espaçamento entre fileiras de plantas, para a maior população, propiciou aumento na produtividade de grãos no genótipo de arquitetura aberta (AG 1051), devido à minimização da competição intra-específica por luz, assumindo-se que não houve limitação na disponibilidade de água e de nutrientes.

O aumento de população ocasionou maior da altura de planta e diminuição do número de fileiras por espiga, grãos por fileira, grãos por espiga, diâmetro de colmo e comprimento da espiga, mas, considerando o objetivo do trabalho, optou-se por não considerar os índices de acamamento de plantas e de quebramento de colmos.

Para os genótipos AG 7575 e DKB 911, não houve efeito significativo do espaçamento sobre a produtividade de grãos e, para o AG 1051, houve diferença entre as produtividades na população mais elevada. Isso permite inferir, a ser comprovado em estudos futuros, que, devido à otimização de interceptação de luz, a redução do espaçamento entre fileiras de plantas tem efeito positivo na produtividade de grãos em alta população, obedecendo à seguinte ordem: 1) genótipo de arquitetura foliar ereta; 2) genótipo de arquitetura foliar semi-ereta; 3) genótipo de arquitetura foliar aberta, desde que não haja limitação de água e nutrientes.

\section{Conclusões}

Efeito do espaçamento de plantas na produtividade de grãos de milho

$\mathrm{Na}$ maior população, a redução do espaçamento (de $0,80 \mathrm{~m}$ para $0,40 \mathrm{~m}$ ) entre fileiras de plantas teve efeito positivo na produtividade de grãos no genótipo de arquitetura foliar aberta (AG 1051), devido à otimização de interceptação de luz.
Efeito da população de plantas na produtividade de grãos de milho

Até 60.000 plantas ha $^{-1}$, independentemente do genótipo, a produtividade de grãos foi crescente com o aumento da população de plantas, mas o aumento de 60.000 para 90.000 plantas ha $^{-1}$ provocou: a) incremento no genótipo de arquitetura ereta (DKB 911); b) estabilidade no genótipo de arquitetura semi-ereta (AG 7575), c) estabilidade, sob espaçamento de $0,40 \mathrm{~m}$, e redução, sob espaçamento de $0,80 \mathrm{~m}$, no genótipo de arquitetura aberta (AG 1051).

\section{Literatura Citada}

CONAB. Safras 2000/01 e 2001/2002. Milho 1a. Safra: Comparativo de Área, Produção e Produtividade. Quadro 11. Disponível em: <http:// www.conab.gov.br.>Acesso em: 12 dez. 2002.

DOURADO NETO, D.; FANCELLI, A. L.; LOPES, P. P. Milho: população e distribuição de plantas. In: FANCELLI, A. L.; DOURADO NETO, D. MILHO: TECNOLOGIA E PRODUTIVIDADE. Piracicaba: SEALQ, 2001.p. 120 - 125.

FANCELLI, A. L.; DOURADO NETO, D. Produção de milho. Guaíba: Agropecuária, 2000.360 p.

FARNHAM, D. E.; MYLI, J.; HADEN, D. Row width and effects on corn yield in Iowa. Disponível em: <http://www.reimangardens.org/ farms/ 2000reports/ NW/ RowWidthanHybridEff My.pdf.> Acesso em : 14 nov. 2002a.

FARNHAM, D. E.; MYLI, J.; HADEN, D. Row width effects on corn yield at varying plant densities. Disponível em: $<$ http: // www.reimangardens.org/ farms/ 2000reports/ mcnay/ RowWidthEffectsonCornY.pdf.> Acesso em: 14 nov. $2002 b$.

FORNASIERI FILHO, D. A cultura do milho. Jaboticabal: Funep, 1992. 273 p. 
JOHNSON, G. A.; HOVERSTAD, T. R.; GREENWALD, R. E. Integrated weed management using narrow corn row spacing, herbicides, and cultivation. Agronomy Journal, Madison, v. 90, n. 1, p. $40-46,1998$.

MOLIN, R. Espaçamento entre linhas de semeadura na cultura de milho. Castro: Fundação $A B C$ para Assistência e Divulgação Técnica Agropecuária, 2000. p. 1-2.

MONTGOMERY, D. C., Design and analysis of experiments. New York: J. Wiley, 1997.

SANGOI, L. Understanding plant density effects on maize growth and development: an important issue to maximize grain yield. Ciência Rural, Santa Maria, v. 31, p. 159 - 168, 2001.

SANGOI, L.; GRACIETTI, M. A.; BIANCHET, P. Híbridos contemporâneos são mais exigentes em população de plantas para maximizarem o rendimento de grãos. (compact disc). In: CONGRESSO NACIONAL DE MILHO E SORGO, 24. 2002, Florianópolis. Anais. Florianópolis: ABMS, 2002.

SERGIO, G. R.; RENZO, G. V. P.; ANDRE, H. B. Alternativas para o arranjo de plantas na cultura do milho. (compact disc). In: CONGRESSO NACIONAL DE MILHO E SORGO, 24. 2002, Florianópolis. Anais. Florianópolis: ABMS, 2002. 